\author{
Ambroży Mituś \\ Katedra Prawa Publicznego \\ Uniwersytet Ekonomiczny w Krakowie
}

\title{
Zlecanie wykonywania zadań z zakresu gospodarowania odpadami komunalnymi*
}

\section{Streszczenie}

Gospodarowanie odpadami komunalnymi stanowi pewien wycinek zadań z zakresu utrzymania czystości i porządku w gminach i wchodzi w skład tzw. gospodarki komunalnej, obejmującej w szczególności zadania o charakterze użyteczności publicznej. Co do zasady jednostki samorządu terytorialnego, w tym gminy, mają swobodę wyboru sposobu prowadzenia i formy gospodarki komunalnej. Do zadań, w przypadku których przepisy szczególne przewidują ograniczenie samodzielności gminy przy wyborze sposobu prowadzenia i formy gospodarki komunalnej, należą zadania z zakresu gospodarowania odpadami komunalnymi. Wykonanie tych zadań może być zlecane tylko po przeprowadzeniu przetargu, do którego w zakresie nieuregulowanym przepisami ustawy o utrzymaniu czystości i porządku w gminach stosuje się ustawę „Prawo zamówień publicznych”. Taki stan prawny pociąga za sobą konieczność stawania do przetargu nawet spółek ze $100 \%$ udziałem gminy oraz wyklucza możliwość wykonywania tych zadań przez własny samorządowy zakład budżetowy.

Słowa kluczowe: odpady komunalne, gospodarowanie odpadami komunalnymi, gospodarka komunalna, zamówienia publiczne.

* W niniejszym artykule częściowo wykorzystano wyniki prowadzonych przez autora w $2011 \mathrm{r}$. badań statutowych pt. „Publicznoprawne aspekty gospodarowania odpadami”. 


\section{Pojęcia odpadu komunalnego i gospodarki odpadami komunalnymi}

W myśl art. 3 ust. 1 pkt 6 ustawy o odpadach [Ustawa z dnia 14 grudnia 2012 r. ...] (dalej: u.o.) odpad to „każdy przedmiot lub substancja, których posiadacz pozbywa się, zamierza się pozbyć lub do których pozbycia się jest zobowiązany”. Odpad powstaje z chwilą, gdy posiadacz - władający substancją lub przedmiotem „,nie znajduje dla niego zastosowania" [Wyrok WSA w Poznaniu z dnia 15 października 2008 r. .... . Bez znaczenia jest to, czy taki odpad „znajdzie w przyszłości jakieś zastosowanie, np. zostanie wykorzystany gospodarczo w innym miejscu i czasie”, a także „stopień zużycia przedmiotu” [Wyrok WSA w Poznaniu z dnia 15 października 2008 r. ...]. O tym, czy dany przedmiot jest odpadem, czy też nim nie jest, przesądza „,nie tylko sam fakt, iż jest uszkodzony, lecz także to, że w związku z tymi uszkodzeniami jego posiadacz postanowił się go wyzbyć" [Wyrok WSA w Warszawie z dnia 20 marca 2008 r. ...]. O uznaniu danego przedmiotu lub substancji za odpad w świetle ustawy o odpadach decyduje zatem wola posiadacza [Wyrok WSA w Warszawie z dnia 12 października 2007 r....].

Zgodnie z ustawą o odpadach posiadaczem odpadów jest ich wytwórca ${ }^{1}$ oraz każdy, kto jest w posiadaniu odpadów (art. 3 ust. 1 pkt 19 u.o.). Posiadaczem odpadów znajdujących się na terenie nieruchomości jest władający tą nieruchomością (na zasadzie domniemania - zob. art. 3 ust. 1 pkt 19 u.o.). To domniemanie ma zastosowanie tylko wówczas, gdy organ nie jest w stanie ustalić wytwórcy lub podmiotu gromadzącego odpady [Wyrok WSA w Gliwicach z dnia 29 lutego 2008 r. ...].

Spośród wielu różnych rodzajów odpadów ustawodawca wyróżnia tzw. odpady komunalne. Pod tym pojęciem rozumie się zarówno odpady powstające w gospodarstwach domowych (jednakże z wyłączeniem pojazdów wycofanych z eksploatacji), jak i odpady pochodzące od ,innych wytwórców odpadów, które ze względu na swój charakter lub skład są podobne do odpadów powstających w gospodarstwach domowych", pod warunkiem, że nie zawierają one odpadów niebezpiecznych (art. 3 ust. 1 pkt 7 u.o.). Posłużenie się przez ustawodawcę określeniem „komunalne” wskazuje przede wszystkim na źródło powstania odpadów²

\footnotetext{
${ }^{1}$ Wytwórcą odpadów jest każdy podmiot, „,którego działalność lub bytowanie powoduje powstawanie odpadów (pierwotny wytwórca odpadów)”, oraz każdy, „kto przeprowadza wstępną obróbkę, mieszanie lub inne działania powodujące zmianę charakteru lub składu tych odpadów; wytwórcą odpadów powstających w wyniku świadczenia usług w zakresie budowy, rozbiórki, remontu obiektów, czyszczenia zbiorników lub urządzeń oraz sprzątania, konserwacji i napraw jest podmiot, który świadczy usługę, chyba że umowa o świadczenie usługi stanowi inaczej” (art. 3 ust. 1 pkt 32 u.o.).

${ }^{2}$ Zob. wyrok WSA w Gdańsku z dnia 2 lutego 2011 r. oraz § 4 ust. 1 Rozporządzenia Ministra Środowiska z dnia 27 września 2001 r. w sprawie katalogu odpadów.
} 
Kolejnym pojęciem niezbędnym do dalszej analizy jest pojęcie gospodarowania odpadami. Rozumiane jest ono przede wszystkim jako zbieranie ${ }^{3}$, transport i przetwarzanie odpadów wraz z czynnościami nadzorczymi nad tego rodzaju działaniami. Do zakresu pojęcia gospodarowania odpadami zalicza się także „późniejsze postępowanie z miejscami unieszkodliwiania odpadów oraz działania wykonywane w charakterze sprzedawcy odpadów lub pośrednika w obrocie odpadami” (art. 3 ust. 1 pkt 2 u.o.).

Pojęcie gospodarowania odpadami jest pojęciem węższym od pojęcia gospodarki odpadami, które obejmuje zarówno wytwarzanie odpadów, jak i gospodarowanie odpadami (art. 3 ust. 1 pkt 3 u.o.). Właściwe gospodarowanie odpadami jest prawnym obowiązkiem wytwórcy odpadów i posiadaczy odpadów.

\section{Wykonywanie zadań z zakresu gospodarowania odpadami komunalnymi}

Zasadnicze obowiązki gmin z zakresu gospodarowania odpadami komunalnymi określa ustawa o utrzymaniu czystości i porządku w gminach [Ustawa z dnia 13 września 1996 r. ...] (dalej: u.u.cz.p.g.). Regulacja ta w art. 3 ust. 1 stanowi, że „utrzymanie czystości i porządku w gminach należy do obowiązkowych zadań własnych gminy", co oznacza, że gmina musi te zadania wykonywać stale i niezależnie od zdolności finansowych ${ }^{4}$. Zadania te wchodzą w skład tzw. gospodarki komunalnej jednostek samorządu terytorialnego, której zasady i formy wykonywania określa ustawa o gospodarce komunalnej [Ustawa z dnia 20 grudnia 1996 r. ...] (dalej: u.g.k.). Zgodnie z art. 1 ust 1 u.g.k. zadania gospodarki komunalnej to zadania własne wykonywane „w celu zaspokojenia zbiorowych potrzeb wspólnoty samorządowej”. Spośród wszystkich zadań gospodarki komunalnej wyodrębnia się tzw. zadania o charakterze użyteczności publicznej5, których celem jest „bieżące i nieprzerwane zaspokajanie zbiorowych potrzeb ludności w drodze świadczenia usług powszechnie dostępnych" (art. 1 ust. 2 u.g.k.). Pojęcie to pojawia się także w art. 9 ust. 4 ustawy o samorządzie gminnym [Ustawa z dnia 8 marca 1990 r. ...]

${ }^{3}$ Zbieranie odpadów to „gromadzenie odpadów przed ich transportem do miejsc przetwarzania, w tym wstępne sortowanie nieprowadzące do zasadniczej zmiany charakteru i składu odpadów i niepowodujące zmiany klasyfikacji odpadów oraz tymczasowe magazynowanie odpadów" przez prowadzącego zbieranie odpadów (art. 3 ust. 1 pkt 34 u.o.).

${ }^{4}$ „W celu realizacji tegoż obowiązku gmina winna podejmować wszelkie działania prawne i organizacyjne oraz czuwać nad prawidłowym wykonywaniem powierzonych zadań w tym zakresie" [Wyrok WSA w Poznaniu z dnia 8 listopada 2011 r. ...].

${ }^{5}$ Zob. [Banasiński i Kulesza 2002, s. 16]. 
wraz z określeniem celów tych zadań („,bieżące i nieprzerwane zaspokajanie zbiorowych potrzeb ludności”).

Z mocy prawa na gminie ciążą obowiązki z zakresu utrzymania czystości i porządku na jej obszarze, dlatego też gmina poza świadczeniem usług (np. w zakresie odbioru odpadów komunalnych) wykonuje szereg zadań o charakterze informacyjnym, ewidencyjnym, sprawozdawczym, nadzorczym i prawotwórczym.

Przejawem prawotwórczości gminy w obszarze zapewnienia czystości i porządku w gminie [Wyrok WSA w Bydgoszczy z dnia 19 października 2010 r....] jest w szczególności Regulamin utrzymania czystości i porządku na terenie gminy, będący aktem prawa miejscowego uchwalanym przez radę gminy po zasięgnięciu opinii państwowego powiatowego inspektora sanitarnego (zob. komentarz do art. 4 u.u.cz.p.g.). Nadzór nad realizacją obowiązków nałożonych na określone podmioty w tym zakresie sprawuje wójt (burmistrz, prezydent miasta).

Zadaniem o charakterze ewidencyjnym jest np. prowadzenie przez wójta (burmistrza, prezydenta miasta) - na mocy art. 9b u.u.cz.p.g. - rejestru działalności regulowanej ${ }^{6}$. Każdy wójt (burmistrz, prezydent miasta) prowadzi rejestr przedsiębiorców odbierających odpady komunalne wytwarzane na terenie danej gminy $^{7}$. Rejestr prowadzi się w formie „bazy danych zapisanej na informatycznych nośnikach danych [...], która może stanowić część innych baz danych z zakresu ochrony środowiska" (art. $9 \mathrm{~b}$ ust. 3 u.u.cz.p.g.).

Wiele zadań (usług) gmina wykonuje na mocy ustawy, a niektóre z nich na mocy uchwał stanowiących akty prawa miejscowego, przejmując w ten sposób obowiązki innych podmiotów. Przykładowo gmina może przejąć od właścicieli nieruchomości obowiązki w zakresie pozbywania się nieczystości ciekłych czy też uprzątnięcia śniegu, błota i innych zanieczyszczeń z chodników położonych wzdłuż nieruchomości (art. 6a ust. 1 u.u.cz.p.g.).

Jednym z istotnych zadań nałożonych na gminy na mocy Ustawy z dnia 1 lipca 2011 r. o zmianie ustawy o utrzymaniu czystości i porządku w gminach oraz niektórych innych ustaw było zbudowanie do dnia 1 lipca 2013 r. gminnego systemu odbioru odpadów komunalnych. W nowym systemie odbiór odpadów komunalnych z nieruchomości zamieszkałych jest obowiązkiem gminy (art. 6c ust. 1 u.u.cz.p.g.). Do odbioru odpadów komunalnych z nieruchomości niezamieszkałych gmina jest zobowiązana tylko wówczas, gdy rada danej gminy podejmie w tym zakresie stosowną uchwałę stanowiącą akt prawa miejscowego (art. 6c ust. 2 u.u.cz.p.g.).

${ }^{6} \mathrm{~W}$ rozumieniu ustawy o swobodzie działalności gospodarczej [Ustawa z dnia 2 lipca 2004 r. ...].

${ }^{7}$ Zob. Uzasadnienie rządowego projektu ustawy o zmianie ustawy o utrzymaniu czystości i porządku w gminach oraz niektórych innych ustaw (druk sejmowy nr 3670), http://orka.sejm.gov.pl/ proc6.nsf/opisy/3670.htm (dostęp: 17.12.2013). 
Gminy $^{8}$ w myśl art. 3 ust. 2 pkt 1 u.u.cz.p.g. są zobowiązane tworzyć warunki do wykonywania prac związanych z utrzymaniem czystości i porządku na swoim terenie lub zapewniać wykonywanie tych prac przez tworzone jednostki organizacyjne, które mogą funkcjonować zarówno w formach publicznoprawnych, jak i prywatnoprawnych. W zakresie działalności organizacyjnej podejmowanej w celu utrzymania porządku i czystości gmina na podległym jej obszarze ma pozycję monopolisty (zob. [Wyrok WSA w Olsztynie z dnia 26 czerwca 2008 r. ...]). Gmina jest zobowiązana m.in. do objęcia właścicieli nieruchomości systemem gospodarowania odpadami komunalnymi oraz do nadzorowania gospodarowania odpadami komunalnymi, w tym nadzorowania realizacji zadań powierzonych podmiotom odbierającym odpady komunalne od właścicieli nieruchomości (art. 3 ust. 2 pkt 3-4 u.u.cz.p.g.).

$\mathrm{Z}$ ustawy o gospodarce komunalnej wynika, że zadania własne gminy mające charakter użyteczności publicznej mogą być wykonywane na dwa sposoby, tj. w drodze zaangażowania własnych jednostek organizacyjnych gminy ${ }^{9}$ lub poprzez zawarcie umów z podmiotami usytuowanymi na zewnętrz danej gminy. Do takiego wniosku prowadzi analiza art. 2-4 u.g.k. (zob. [Mituś 2011, s. 125-146]). Potwierdził to także Naczelny Sąd Administracyjny w wyroku z dnia 11 sierpnia 2005 r. ${ }^{10}$, stwierdzając, że przepisy ustaw o samorządzie gminnym i o gospodarce komunalnej są ze sobą ,ściśle powiązane” i wynika z nich, że „w zakresie wykonywania zadań użyteczności publicznej gmina może przyjąć dwa różne rozwiązania organizacyjne [...]. Wykonywanie przez gminę zadań komunalnych we własnym zakresie - przez utworzoną w tym celu jednostkę organizacyjną [...] zawarcia umowy nie wymaga" [Wyrok NSA z dnia 11 sierpnia 2005 r. ...]. Podstawą powierzenia wykonywania zadań komunalnych jest ,akt organu gminy powołujący do życia tę jednostkę i określający przedmiot jej działania" [Wyrok NSA z dnia 11 sierpnia 2005 r. ...]. Oznacza to, że do wykonania zadań o charakterze użyteczności publicznej przez jednostkę organizacyjną utworzoną w tym celu przez gminę nie stosuje się przepisów z zakresu zamówień publicznych.

Należy jednak zaznaczyć, że w myśl art. 4 ust. 1 u.g.k. swoboda wyboru sposobu prowadzenia i form gospodarki komunalnej może być ograniczona przez przepisy szczególne.

${ }^{8} \mathrm{~W}$ przypadku wykonywania zadań z zakresu utrzymaniu czystości i porządku w gminach przez związek międzygminny prawa i obowiązki organów gminy wykonują organy związku.

${ }^{9} \mathrm{~W}$ literaturze warunki dopuszczalności zlecania przez gminę własnej spółce realizacji zadania publicznego z wyłączeniem ustawy „Prawo zamówień publicznych” określa się kategorią tzw. zamówień in house.

${ }^{10}$ Do przedmiotowego wyroku krytycznie odniósł się R. Szostak [2006, s. 139-145], natomiast aprobująco - Z. Czarnik [2006, s. 74-80]. 


\section{Formy i tryby zlecania realizacji zadań z zakresu gospodarowania odpadami komunalnymi}

Do zadań, w przypadku których przepisy szczególne przewidują ograniczenie samodzielności gmin w zakresie sposobów prowadzenia i form gospodarki komunalnej, należą właśnie zadania z zakresu gospodarowania odpadami komunalnymi. Na mocy przepisu art. 6e u.u.cz.p.g. ograniczono sposoby realizacji zadań własnych gminy, tj. wyłączono możliwość wykonywania przez gminy przy pomocy własnych spółek zadań z zakresu odbioru i gospodarowania odpadami komunalnymi. Wyłączono również możliwość wykonywania przez te spółki zadań polegających na odbiorze odpadów komunalnych bez konieczności przeprowadzenia przetargu. Jedyną możliwą formą zlecenia realizacji zadania przez gminę jest forma cywilnoprawna - umowa zawarta po przeprowadzeniu przetargu. $\mathrm{Na}$ podstawie analizy przepisów art. 6d-6g u.u.cz.p.g. można wnioskować, że wyłączono także możliwość wykonywania zadań z zakresu odbioru i gospodarowania odpadami komunalnymi w formach publicznoprawnych (tj. w formie samorządowego zakładu budżetowego). Jest to spowodowane m.in. tym, że ustawa wymaga przeprowadzenia przetargu, w wyniku którego dochodzi do zawarcia umowy, a nie można przecież zawrzeć prawnie skutecznej umowy z własną jednostką organizacyjną nieposiadającą osobowości prawnej. Jeśli zatem samorządowe zakłady budżetowe chcą wykonywać te zadania, muszą przekształcić się w spółkę prawa handlowego, a następnie stanąć do przetargu. Czy jednak na pewno? Wątpliwości w tym zakresie wprowadzają same przepisy ustawy o utrzymaniu czystości i porządku w gminach, które oprócz pojęcia przedsiębiorcy posługują się pojęciem podmiotu odbierającego odpady komunalne, które jest pojęciem szerszym od pojęcia przedsiębiorcy (zob. np. art. 9k u.u.cz.p.g.). Wśród tych przepisów istotne znaczenie ma art. 15 Ustawy dnia 1 lipca 2011 r. o zmianie ustawy o utrzymaniu czystości i porządku w gminach oraz niektórych innych ustaw, stanowiący, że gminne jednostki organizacyjne, które w dniu wejścia w życie ustawy wykonują działalność w zakresie odbierania odpadów komunalnych od właścicieli nieruchomości, są zobowiązane dostosować się do wymagań dotyczących tego odbioru w okresie 12 miesięcy od dnia wejścia w życie ustawy. Nie mówi się zatem o zmianie dotyczącej formy, lecz „wymagań odbioru”. Argumenty za i przeciw można by mnożyć i rzeczywiście pojawia się ich wiele na łamach literatury fachowej (np. że ustawodawca nie zobowiązuje do przekształcenia samorządowych zakładów budżetowych w spółki prawa handlowego). Należy jednak sformułować odpowiedź (określić normę) na to przewijające się zasadnicze pytanie: czy gminne jednostki organizacyjne nieposiadające osobowości prawnej mogą, czy też nie mogą wykonywać zadania z zakresu odbioru i gospodarowania odpadami komunalnymi? Z uwagi na całokształt regulacji prawnych wydaje się, 
że należy wywieść następującą normę: gminne jednostki organizacyjne mogą wykonywać szereg zadań z zakresu utrzymania porządku i czystości w gminie, jednakże poza odbieraniem odpadów komunalnych od właścicieli nieruchomości oraz odbieraniem i zagospodarowaniem tych odpadów, chyba że odbiór odpadów komunalnych odbywa się na zlecenie właścicieli nieruchomości niezamieszkanych i nie istnieje w tym zakresie stosowna uchwała rady gminy o przejęciu obowiązku odbioru przez gminę. Gminne jednostki organizacyjne, w tym samorządowe zakłady budżetowe, mogą zatem wykonywać tylko te zadania, które nie są objęte gminnym systemem odbioru odpadów komunalnych.

Należy podkreślić, że samorządowy zakład budżetowy nie może być także podmiotem zarządzającym gminnym składowiskiem odpadów. Wynika to z art. 136 u.o., który stanowi, że takim zarządzającym nie może być jednostka sektora finansów publicznych. Jeżeli składowiskiem odpadów zarządza gminna jednostka sektora finansów publicznych, gmina była zobowiązana do dnia 23 stycznia 2014 r. (zob. art. $243 \mathrm{w}$ związku z art. 253 u.o.) albo utworzyć podmiot niebędący taką jednostką (np. dokonać przekształcenia takiego zakładu budżetowego w spółkę z udziałem gminy), albo „powierzyć wykonywanie praw i obowiązków zarządzającego gminnym składowiskiem odpadów podmiotowi niebędącemu jednostką sektora finansów publicznych" na zasadach określonych w ustawie o gospodarce komunalnej.

Zgodnie z art. 6d ust. 1 u.u.cz.p.g. wójt (burmistrz, prezydent miasta) jest zobowiązany zorganizować przetarg na odbieranie odpadów komunalnych od właścicieli nieruchomości albo przetarg na odbieranie i zagospodarowanie tych odpadów. Przeprowadzenie przetargu wyłącznie na odbiór odpadów komunalnych powoduje, że gmina poprzez własne jednostki musi zagospodarować zebrane odpady.

W celu zorganizowania odbierania odpadów komunalnych od właścicieli nieruchomości rada w gminie liczącej ponad 10 tys. mieszkańców może podjąć uchwałę stanowiącą akt prawa miejscowego o podziale terytorium gminy na sektory (art. 6d ust. 2 u.u.cz.p.g.). Przy podziale gminy na sektory bierze się pod uwagę liczbę mieszkańców, gęstość zaludnienia oraz obszar możliwy do obsługi przez jednego przedsiębiorcę odbierającego odpady komunalne (art. $6 \mathrm{~d}$ ust. 2 u.u.cz.p.g.).

W przypadku, gdy gmina jest podzielona na sektory, przetargi na odbieranie odpadów komunalnych od właścicieli nieruchomości oraz na odbieranie i zagospodarowanie tych odpadów organizuje się odrębnie dla każdego z wyznaczonych sektorów (art. 6d ust. 3 u.u.cz.p.g.). Istota takiego rozwiązania zasługuje na uznanie, gdyż nie monopolizuje rynku odbiorców odpadów komunalnych tylko do dużych podmiotów (lub konsorcjów) dysponujących dużym potencjałem technicznym; a tak by mogło być, gdyby należało przeprowadzić jeden przetarg dla danej gminy niezależnie od jej wielkości. Wydaje się, że podział gminy na sektory 
wyłącza możliwość przeprowadzenia dla całej gminy jednego postępowania o udzielnie zamówienia publicznego. Taka możliwość istnieje tylko w przypadku braku podziału gminy na sektory - wówczas w takim postępowaniu zamawiający może dopuścić możliwość składania ofert częściowych, obejmujących np. wyodrębnione już dzielnice.

W kontekście możliwości tworzenia sektorów i przeprowadzania przetargów oddzielnie dla każdego z nich pojawia się wątpliwość dotycząca ustalania wartości zamówienia. Chodzi mianowicie o to, czy w danym przetargu (postępowaniu o udzielenie zamówienia publicznego na odbiór odpadów komunalnych) wartością zamówienia jest wartość ustalona tylko dla danego sektora, dla którego przeprowadza się przetarg, czy też wartością zamówienia jest suma wartości ustalonych dla wszystkich sektorów danej gminy (zamawiającego). Kwestię tę można sprowadzić do pytania, czy przepisy ustawy o utrzymaniu czystości i porządku w gminach wprowadzają wyjątek od zakazu dzielenia zamówienia na części, określonego w ustawie „Prawo zamówień publicznych” [Ustawa z dnia 29 stycznia 2004 r. ...], czy też nie, i czy w ogóle mamy w tym przypadku do czynienia z dzieleniem zamówienia na części. W samej ustawie o utrzymaniu czystości i porządku w gminach nie ma zapisów na temat ustalania wartości zamówienia. Oznacza to sięgnięcie do ustawy „Prawo zamówień publicznych”, która w tym zakresie w art. 32 ust. 2 formułuje zakaz dzielenia zamówienia na części w sposób, który prowadziłby do uniknięcia stosowania jej przepisów. Dzielenie zamówienia na części możliwe jest tylko w przypadku i na warunkach określonych w art. 32 ust. 4 i art. 6a ustawy „Prawo zamówień publicznych”; ten ostatni przepis jest pewną modyfikacją zasad określonych w art. 32 ust. 4.

Podejmując próbę odpowiedzi na postawione pytania, należy mieć na uwadze fakt, że zakaz dzielenia zamówienia na części jest wyrazem stosowania głównej zasady zamówień publicznych, jaką jest zasada konkurencyjności. Dzięki niej oraz dzięki zakazowi dzielenia zamówienia na części krąg potencjalnych wykonawców składa się nie tylko z podmiotów lokalnych czy krajowych, ale i z podmiotów działających na wspólnym rynku Unii Europejskiej.

Wydaje się, że kwestię ustalania wartości zamówienia i niedozwolonego podziału zamówienia na części można sprowadzić do możliwości lub braku możliwości przeprowadzenia jednego postępowania. $\mathrm{Z}$ niedozwolonym podziałem zamówienia na części mamy de facto do czynienia wówczas, gdy można przeprowadzić jedno postępowanie, a przeprowadza się kilka postępowań w taki sposób, że unika się stosowania przepisów ustawy (tj. unika się stosowania przepisów ustawy właściwych dla trybu pełnego lub unika się stosowania przepisów ustawy „Prawo zamówień publicznych” w ogóle). W przetargach na odbiór odpadów komunalnych w gminach podzielonych na sektory nie ma możliwości przeprowadzenia jednego postępowania. Każdy przetarg na odbiór odpadów komunalnych 
w danym sektorze jest przetargiem samoistnym. Na uwagę zasługuje także fakt, że podział obszaru gminy na sektory (a pośrednio podział przedmiotu zamówienia) nie odbywa się w dowolnej formie, lecz w formie uchwały organu stanowiącego, będącej aktem prawa miejscowego, o czym informuje expressis verbis art. $6 \mathrm{~d}$ ust. 2 u.u.cz.p.g.

Niezależnie od powyższych wątpliwości uprawnione wydaje się stwierdzenie, że dla każdego sektora należy dokonać odrębnego ustalenia wartości zamówienia. Przemawia za tym to, że przetargi, o których mowa w ustawie o utrzymaniu czystości i porządku w gminach, należy traktować jako samoistne instytucje prawne. Ponadto dokonywany podział przedmiotu zamówienia nie odbywa się w ramach przygotowywania (planowania) i podejmowania czynności mających na celu przeprowadzenie postępowania o udzielnie zamówienia publicznego, lecz dokonywany jest wcześniej i niezależnie od danego postępowania. Należy tutaj zauważyć, że podział gminy na sektory, a w konsekwencji podział przedmiotu zamówienia, następuje $\mathrm{w}$ formie właściwej dla prawa administracyjnego, podczas gdy podział przedmiotu zamówienia, o którym mowa w ustawie „Prawo zamówień publicznych”, następuje w formie właściwej dla prawa cywilnego.

Opowiedzenie się za możliwością odrębnego ustalenia wartości zamówienia dla każdego sektora prowadzi do swoistego dualizmu w ustalaniu wartości zamówienia w przedmiocie odbioru odpadów komunalnych w poszczególnych gminach, w zależności od tego, czy gmina jest (jeśli ma taką możliwość), czy nie jest podzielona na sektory. Wydaje się jednak, że w gminach, w których jest to możliwe, podział jej obszaru na sektory będzie dokonywany choćby ze względu na ograniczenie ryzyka związanego z trudnościami w rozstrzygnięciu przetargu. Jeśli bowiem doszłoby do takich trudności, dotyczyłyby one (i ewentualnie dotknęłyby mieszkańców) tylko określonego sektora, a w pozostałych nastąpiłoby zlecenie wykonania zadania; oczywiście podobny efekt można uzyskać przy składaniu ofert częściowych.

Zgodnie z brzmieniem przywoływanego już art. 6g u.u.cz.p.g. do „przetargów, [...] w zakresie nieuregulowanym w niniejszej ustawie stosuje się Ustawę z dnia 29 stycznia 2004 r. - Prawo zamówień publicznych". Takie sformułowanie powoduje, że „przetarg” w rozumieniu cytowanej ustawy nie jest trybem udzielania zamówień publicznych, a spośród wszystkich trybów udzielania zamówień publicznych przewidzianych ustawą „Prawo zamówień publicznych” znajdą zastosowanie tylko dwa tryby (tj. tryb przetargu nieograniczonego i ograniczonego). Zapis ten przesądza o tym, że ustawodawca wymaga, aby zlecanie tego rodzaju zadań następowało w sposób jak najbardziej konkurencyjny. Stosowanie trybu przetargu nieograniczonego i ograniczonego jest bowiem zasadą przy zamówieniach publicznych; ich stosowanie nie wymaga spełnienia jakichkolwiek przesłanek.

Przepisy ustawy o utrzymaniu czystości i porządku w gminach (art. 6d ust. 4) określają także dodatkowe elementy, jakie powinny znaleźć się w specyfikacji 
istotnych warunków zamówienia (SIWZ) na odbiór odpadów komunalnych. SIWZ powinna określać w szczególności: wymagania stawiane przedsiębiorcom odbierającym odpady komunalne, rodzaje odpadów odbieranych selektywnie od właścicieli nieruchomości, wymogi dotyczące przekazywania odebranych zmieszanych odpadów komunalnych, standard sanitarny wykonywania usług itd.

$\mathrm{Z}$ przedsiębiorcą wybranym $\mathrm{w}$ drodze przetargu zawiera się umowę na odbieranie odpadów komunalnych od właścicieli nieruchomości (art. $6 \mathrm{f}$ ust. 1 u.u.cz.p.g.). W przypadku rozwiązania umowy na odbieranie odpadów komunalnych wójt (burmistrz, prezydent miasta) jest zobowiązany niezwłocznie zorganizować przetarg. W celu zapewnienia odbierania odpadów komunalnych z terenu gminy do czasu rozstrzygnięcia przetargu gmina dokonuje wyboru wykonawcy w trybie zamówienia z wolnej ręki zgodnie z ustawą „Prawo zamówień publicznych" (art. 6 f ust. 2 u.u.cz.p.g.).

W przypadku, gdy gmina nie wykonuje obowiązku odbierania odpadów komunalnych od właścicieli nieruchomości, właściciel jest zobowiązany do przekazania na koszt gminy odpadów komunalnych podmiotowi odbierającemu odpady komunalne od właścicieli nieruchomości, wpisanemu do rejestru działalności regulowanej (art. 6s u.u.cz.p.g.).

Gmina, wykonując zadania polegające na zapewnieniu budowy, utrzymania i eksploatacji regionalnych instalacji do przetwarzania odpadów komunalnych (zakład zagospodarowania odpadów o odpowiedniej mocy przerobowej, zapewniający termiczne przekształcanie lub stosowne przetwarzanie odpadów) ${ }^{11}$, zgodnie $\mathrm{z}$ art. 3a, ust. 1 u.u.cz.p.g. jest zobowiązana do: dokonania w drodze przetargu wyboru podmiotu, który będzie budował, utrzymywał lub eksploatował taką instalację, lub na zasadach określonych w ustawie o partnerstwie publiczno-prywatnym [Ustawa z dnia 19 grudnia 2008 r. ...], lub też na zasadach określonych w ustawie o koncesji na roboty budowlane lub usługi [Ustawa z dnia 9 stycznia 2009 r. ...]. W przypadku, gdy nie uda się zlecić realizacji tych zadań w drodze przetargu (tj. gdy prowadzone postępowanie przetargowe nie doprowadzi do wyboru oferty najkorzystniejszej i wyłonienia wykonawcy) albo gdy nie zostanie dokonany wybór partnera prywatnego, lub też gdy nie zostanie dokonany wybór koncesjonariusza, „gmina może samodzielnie realizować zadanie polegające na budowie, utrzymaniu lub eksploatacji regionalnej instalacji do przetwarzania odpadów komunalnych" (art. 3a ust. 2 u.u.cz.p.g.). Powyższe ograniczenia nie dotyczą instalacji wskazanej w wojewódzkim planie gospodarki odpadami jako zakład zagospodarowania odpadów, dla którego przed 1 stycznia 2012 r. wydano decyzję o środowiskowych uwarunkowaniach lub decyzję o warunkach zabudowy i zagospodarowania terenu, lub którego budowa lub eksploatacja rozpoczęła się przed

${ }^{11}$ Definicję legalną „regionalnej instalacji do przetwarzania odpadów komunalnych” formułuje art. 3 ust. 3 pkt $15 \mathrm{c}$ u.o. 
1 stycznia 2012 r. (art. 19 Ustawy z dnia 1 lipca 2011 r. o zmianie ustawy o utrzymaniu czystości i porządku w gminach oraz niektórych innych ustaw).

\section{Zakończenie}

Współcześnie zadania publiczne są wykonywane zarówno przez podmioty publiczne, jak i podmioty prywatne i społeczne ${ }^{12}$. Zadania z zakresu utrzymania czystości i porządku w gminie to część gminnej gospodarki komunalnej w ramach której gminy co do zasady mają wybór sposobu i form jej wykonywania; zadania publiczne mogą być wykonywane zarówno za pomocą instrumentów cywilnoprawnych, jak i administracyjnoprawnych. Możliwość wyboru sposobu i form wykonywania zadań z zakresu gospodarowania odpadami komunalnymi przez gminę jest natomiast ograniczona - zadania te mogą wykonywać tylko podmioty wybrane w drodze przetargu.

Zadanie przekazane do wykonania podmiotom zewnętrznym nie traci charakteru publicznego, choć de facto jest usługą świadczoną przez podmiot prywatny czy społeczny (zob. [Analiza instytucjonalna... 2004, s. 55]). Gmina w takim wypadku pełni tylko funkcję organizatora wykonywanych usług, określając zasady i standardy ich świadczenia, a także zapewniając ich stosowne finansowanie. Zadania te wykonywane są na zasadach rynkowych, zgodnie z którymi koszty świadczenia przedmiotowych usług pokrywają świadczeniobiorcy.

Gmina, powierzając wykonywanie zadań publicznych podmiotom zewnętrznym, nadal ponosi odpowiedzialność publicznoprawną za ich realizację, a podmiot zewnętrzny - odpowiedzialność cywilnoprawną [Prawo administracyjne... 2008, s. 122] - czy to z tytułu niewykonania, czy też nienależytego wykonania zleconego zadania (zob. [Mituś 2012, s. 442-455]).

Analizując przepisy prawne dotyczące wykonywania zadań z zakresu gospodarki odpadami komunalnymi (utrzymanie czystości i porządku w gminie), można wyciągnąć pewne wnioski. Zasadniczo idea systemu gospodarki odpadami komunalnymi zasługuje na aprobatę, gdyż - zgodnie z założeniami rządowymi - system ten ma na celu stworzenie na terenie całego kraju jednolitych zasad odbierania, finansowania i zagospodarowywania odpadów komunalnych, a ponadto ma na celu m.in. uszczelnienie systemu gospodarowania odpadami komunalnymi,

${ }^{12}$ Zlecanie wykonywania zadań publicznych może nastąpić w szczególności na mocy przepisów ustawy o finansach publicznych [Ustawa z dnia 27 sierpnia 2009 r. ...], w trybie przepisów ustawy o partnerstwie publiczno-prywatnym [Ustawa z dnia 19 grudnia 2008 r. ...], ustawy o koncesji na roboty budowlane lub usługi [Ustawa z dnia 9 stycznia 2009 r. ...], ustawy „Prawo zamówień publicznych" [Ustawa z dnia 29 stycznia 2004 r. ...], ustawy o działalności pożytku publicznego i o wolontariacie [Ustawa z dnia 24 kwietnia 2003 r. ...] czy też na zasadach określonych w kodeksie cywilnym [Ustawa z dnia 23 kwietnia 1964 r. ...] jako lex generalis. 
zmniejszenie ilości odpadów i prowadzenie selektywnego zbierania odpadów komunalnych, wyeliminowanie dzikich wysypisk śmieci i nielegalnych składowisk odpadów; monitorowanie postępowania z odpadami komunalnymi [Uzasadnienie rządowego projektu...]. Wyłączając możliwość odbierania odpadów komunalnych albo odbierania i zagospodarowania tych odpadów bezpośrednio przez gminy w formie publicznoprawnej, ustawodawca chciał zwiększyć konkurencyjność i innowacyjność w tym obszarze oraz wyeliminować praktyki ograniczające konkurencję. Wydaje się to o tyle słuszne, że działalność tego rodzaju podejmuje wielu przedsiębiorców, co stwarza konkurencję, a zatem podnosi jakość i efektywność świadczonych usług. Choć cel ten zasadniczo zasługuje na uznanie, nie można już tego powiedzieć o konkretnych rozwiązaniach prawnych. Przykładowo taka stosunkowo szybka zmiana stanu prawnego może dla spółek gminnych powołanych do wykonywania zadań z zakresu gospodarowania odpadami komunalnymi nastręczać wiele trudności, zwłaszcza gdy poczyniono już jakieś inwestycje. Ich finansowanie ze środków unijnych może powodować dodatkowe problemy związane np. z nieuzyskaniem zakładanych efektów.

Należy też zauważyć, że wyeliminowanie monopolu jednostek gminnych nie eliminuje monopolu w ogóle, lecz stwarza możliwość stworzenia monopolu przez podmioty prywatne (konsorcja), które początkowo oferują wykonanie zadania niejednokrotnie na granicy opłacalności w celu pozbycia się konkurencji z rynku, by następnie podnieść ceny świadczonych usług. To zjawisko jest coraz bardziej dostrzegalne w wielu obszarach zlecania wykonywania zadań podmiotom zewnętrznym.

\section{Literatura}

Analiza instytucjonalna urzędu gminy. Przewodnik dla samorządów [2004], red. M. Zawicki, S. Mazur, wyd. 2, Małopolska Szkoła Administracji Publicznej Akademii Ekonomicznej w Krakowie, Kraków.

Banasiński C., Kulesza M. [2002], Ustawa o gospodarce komunalnej. Komentarz, Dom Wydawniczy ABC, Warszawa.

Czarnik Z. [2006], Glosa, ,Samorząd Terytorialny”, nr 5.

Mituś A. [2011], Istota wykonywania zadań publicznych z zakresu gospodarki komunalnej, Zeszyty Naukowe Uniwersytetu Ekonomicznego w Krakowie, nr 868, Kraków.

Mituś A. [2012], Odpowiedzialność odszkodowawcza jednostek samorzqdu terytorialnego w zakresie wykonywania zadań z zakresu gospodarki komunalnej-zagadnienia wybrane [w:] Władztwo administracyjne. Administracja publiczna w sferze imperium $i$ w sferze dominium, red. J. Łukasiewicz, TNOiK, Rzeszów.

Prawo administracyjne [2008], red. E. Ura, Wydawnictwo Prawnicze LexisNexis, Warszawa.

Szostak R. [2006], Glosa, ,Samorząd Terytorialny”, nr 1-2. 
Uzasadnienie rządowego projektu ustawy o zmianie ustawy o utrzymaniu czystości i porządku w gminach oraz niektórych innych ustaw (druk sejmowy nr 3670), http://orka.sejm.gov.pl/proc6.nsf/opisy/3670.htm (dostęp: 17.12.2013).

\section{Akty normatywne}

Rozporządzenie Ministra Środowiska z dnia 27 września 2001 r. w sprawie katalogu odpadów, Dz.U., nr 112, poz. 1206.

Ustawa z dnia 23 kwietnia 1964 r. „Kodeks cywilny”, Dz.U. z 2014 r., poz. 121.

Ustawa z dnia 8 marca 1990 r. o samorządzie gminnym, Dz.U. z 2013 r., poz. 594.

Ustawa z dnia 13 września 1996 r. o utrzymaniu czystości i porządku w gminach, Dz.U. z 2013 r., poz. 1399.

Ustawa z dnia 20 grudnia 1996 r. o gospodarce komunalnej, Dz.U. z 2011 r., nr 45, poz. 236.

Ustawy z dnia 24 kwietnia 2003 r. o działalności pożytku publicznego i o wolontariacie, Dz.U. z 2010 r., nr 234, poz. 1536.

Ustawa z dnia 29 stycznia 2004 r. „Prawo zamówień publicznych”, Dz.U. z 2013 r., poz. 907.

Ustawa z dnia 2 lipca 2004 r. o swobodzie działalności gospodarczej, Dz.U. z 2013 r., poz. 672 .

Ustawa z dnia 19 grudnia 2008 r. o partnerstwie publiczno-prywatnym, Dz.U. z 2009 r., nr 19, poz. 100.

Ustawa z dnia 9 stycznia 2009 r. o koncesji na roboty budowlane lub usługi, Dz.U., nr 19, poz. 101.

Ustawa z dnia 27 sierpnia 2009 r. o finansach publicznych, Dz.U. z 2013 r., poz. 885.

Ustawa z dnia 1 lipca 2011 r. o zmianie ustawy o utrzymaniu czystości i porządku w gminach oraz niektórych innych ustaw, Dz.U. z 2011 r., nr 152, poz. 897.

Ustawa z dnia 14 grudnia 2012 r. r. o odpadach, Dz.U. z 2013 r., poz. 21.

\section{Orzecznictwo}

Wyrok NSA z dnia 11 sierpnia 2005 r., II GSK 105/2005, ONSAiWSA 2006, nr 2, poz. 62; LexPolonica, nr 389852.

Wyrok WSA w Bydgoszczy z dnia 19 października 2010 r., II SA/Bd 724/2010, LexPolonica, nr 2519815.

Wyrok WSA w Gdańsku z dnia 2 lutego 2011 r., II SA/Gd 769/2010, LexPolonica, nr 2589999.

Wyrok WSA w Gliwicach z dnia 29 lutego 2008 r., II SA/Gl 1022/2007, LexPolonica, nr 2037336.

Wyrok WSA w Olsztynie z dnia 26 czerwca 2008 r., II SA/Ol 258/2008, LexPolonica, nr 1961811.

Wyrok WSA w Poznaniu z dnia 15 października 2008 r., II SA/Po 58/2008, LexPolonica, nr 2037370.

Wyrok WSA w Poznaniu z dnia 8 listopada 2011 r., IV SA/Po 717/2011, LexPolonica, nr 3851186.

Wyrok WSA w Warszawie z dnia 12 października 2007 r., IV SA/Wa 1337/2007, LexPolonica, nr 2039379.

Wyrok WSA w Warszawie z dnia 20 marca 2008 r., IV SA/Wa 161/2008, LexPolonica, nr 1893223. 


\section{Outsourcing Municipal Waste Management}

Waste management is one of the tasks of maintaining cleanliness and order in municipalities. It's a fragment of the municipal economy, which includes, in particular, tasks related to public services. As a rule, local governments, including municipalities, are free to choose how and in which form to conduct municipal management. One of the tasks, where the particular regulations provide for limiting municipality autonomy in choosing the methods and forms of conducting municipal management is related to municipal waste management. Tasks carried out in this area may be delegated only after public tender, which is mostly regulated by the Public Procurement Act. Such a legal status means that even municipal companies must stand for tender, and self-government financial institutions are prevented from performing these tasks.

Keywords: municipal waste, municipal waste management, municipal economy, public procurement. 